simple measures of quality, we must not lose sight of our goals and our science.

\section{REFERENCES}

1. Theaetetus. In: Edman I, ed. The W orks of Plato. The Modem Library. New York, NY: Random House Inc; 1956:575.
2. Met-tens R, Van den Berg JM, Veerman-Brenzikofer MLV, Kurz $\mathrm{X}$, Jans B, Klazinga $\mathrm{N}$. International comparison of results of infection surveillance: The Netherlands versus Belgium. Infect Control H osp Epidemiol 1994;15:573-579.

3. Theaetetus. In: Edman I, ed. The W orks of Plato. The Modern Library. New York, NY: Random House Inc; 1956:499.

\title{
Abstracts for the 1995 International AIDS Conference on CD-ROM
}

\section{by Gina Pugliese, RN, MS Medical News Editor}

For the first time, the conference abstracts of the 10th International Conference on AIDS (acquired immunodeficiency syndrome) held in Yokohama, Japan, August 7-12, 1994, will be available on CD-ROM. Topics will include AIDS treatments and pharmaceutical com- pany results, TB, blood safety, infection control and hospital issues, epidemiology, drug resistance, vaccines, AIDS related cancers, government issues, and university research. To order the abstracts on CD-ROM from C.W. Henderson publishers, call (800) 633-4931; or E-mail to info@hendersonnet.atl.ga.us on Internet.

The University of California, Los
Angeles, AIDS Institute sponsored an AIDS symposium on 'Treatment of HIV Disease: Advances and Future Challenges," August 12,1994, in conjunction with the 10th International Conference on AIDS. Complimentary proceedings and video cassettes of the symposium will be available in the fall.

FROM: AIDS Weekly July 11, 1994:2. Also July 18, 1994:6 